\title{
Article \\ The Role of the External Accountant in Business Planning for Starters: Perspective of the Self-Determination Theory
}

\author{
Stefanie De Bruyckere ${ }^{1, *(D)}$ and Patricia Everaert ${ }^{2}$ (D) \\ 1 School of Business and Management, University of Applied Sciences and Arts (HOGENT), \\ Valentin Vaerwyckweg 1, 9000 Ghent, East Flanders, Belgium \\ 2 Department of Accounting, Corporate Finance and Taxation, Faculty of Economics and Business \\ Administration, Ghent University (UGent), Sint-Pietersplein 7, 9000 Ghent, East Flanders, Belgium; \\ Patricia.everaer@@ugent.be \\ * Correspondence: Stefanie.debruyckere@hogent.be; Tel.: +32-9-243-38-22
}

Citation: De Bruyckere, S.; Everaert, P. The Role of the External Accountant in Business Planning for Starters: Perspective of the Self-Determination Theory. Sustainability 2021, 13, 3014. https://doi.org/10.3390/su13063014

Academic Editor: Tensie Steijvers

Received: 1 February 2021

Accepted: 8 March 2021

Published: 10 March 2021

Publisher's Note: MDPI stays neutral with regard to jurisdictional claims in published maps and institutional affiliations.

Copyright: (c) 2021 by the authors. Licensee MDPI, Basel, Switzerland. This article is an open access article distributed under the terms and conditions of the Creative Commons Attribution (CC BY) license (https:// creativecommons.org/licenses/by/ $4.0 /)$.

\begin{abstract}
The objective of this study was to gain more insight into the value of business planning for starters and to better understand the role of the external accountant in the planning stage. In particular, survey research was conducted to capture both the quality of the business plan and its effectiveness as perceived by the starter. To unravel the underlying reasons behind the development of a business plan, the framework of the self-determination theory (SDT) was used and adapted to this context. SDT proposes a continuum that distinguishes four types of motivation, ranging from external motivation (i.e., developing a business plan because of a legal obligation) to intrinsic motivation (i.e., developing a business plan because of a personal interest). The results, based on 283 surveys of Belgian starters, showed a relationship between the type of motivation and the quality of the business plan. Entrepreneurs with high introjected or high identified motivation seem to develop a high-quality business plan. This high-quality business plan enables entrepreneurs to increase their effectiveness. Furthermore, entrepreneurs who consulted an accountant during the business planning stage perceived the quality of their business plan as higher than entrepreneurs who did not get advice from an accountant. These findings presuppose an important challenge for external accountants, as their business advice supports entrepreneurs in anticipating "the unexpected", which subsequently empowers them to monitor their business effectively.
\end{abstract}

Keywords: business planning; starters; self-determination theory; external accountant; effectiveness

\section{Introduction}

On average, $99 \%$ of all European businesses are represented by small- and mediumsized enterprises (SMEs) [1]. These SMEs play a key role in creating added value, as they employ approximately 100 million people and account for more than half of the European gross domestic product [2]. Furthermore, SMEs fulfill an important role in tackling sustainability challenges such as climate change, the increasing scarcity of natural resources, and social cohesion $[2,3]$. Thus, as is commonly known and accepted, entrepreneurship is an important driver of the European-and also the Belgian-economy. In this respect, starters render a major contribution to modern society [4]. They translate innovative plans and opportunities into new business projects that generate financial, natural, cultural, and/or social value [1]. Therefore, governmental organizations, public institutions, and entrepreneurial education programs stimulate (nascent) entrepreneurs to realize their innovative and creative ideas [2].

However, when preparing the launch of a new business, entrepreneurs often struggle with several uncertainties. In order to prepare for "the unexpected" and make wellinformed decisions, nascent entrepreneurs are strongly encouraged to develop a business plan [5,6]. Fernández-Geurrero et al. [7] (p. 2403), defined a business plan as “a written 
document that systematically and in an orderly fashion details a firm's strategic and operative aspects and should therefore allow for the assessment of a business project's economic, financial, commercial, and legal administrative viability." Creating a business plan in which the economic, organizational, and financial feasibility are forecasted should thus enable entrepreneurs to make substantiated choices when they start their business [7-13]. This rationale supports the idea that "planning before taking action improves the quality of most human action" [14] (p. 1167). The business plan is therefore assumed to be a very valuable instrument to identify opportunities and possible threats or problems in advance [15]. Moreover, this plan should enable entrepreneurs to make the right decisions based on relevant data and to subsequently assess the overall viability of the company $[7,14,16-20]$.

However, it is striking that entrepreneurs seem to primarily detail the commercial and organizational aspects of their project in a business plan and pay less attention to the financial aspects [21]. The financial translation of their business project is often perceived as difficult, especially because of the uncertain factors that entrepreneurs need to capture [22]. Moreover, the descriptive parts of the business plan often do not seem to correspond with the financial information [23]. Previous studies have also found that owners of young businesses seem to apply inaccurate methods of decision making and information processing [23,24]. Bagire and Namada [25] pointed out that "there is less emphasis on financial capability in empirical studies" ( . . . ) while "financial capability is enumerated as a precursor to strategic decisions, hence influencing the level of effectiveness" (pp. 480, 482). As the interpretation and use of financial data seem to represent an obstacle for entrepreneurs in the preparation of their business plan-and subsequently in monitoring their financial management-this topic deserves more attention [21,26-31].

Business planning thus requires a thorough analysis of various domains including financial topics. Thus, developing a business plan means that an entrepreneur is challenged to reflect thoroughly on very diverse aspects of the business project. The existing literature argues that the development of a business plan is valuable if this business plan is considered as a guideline for decision making. Then, it enables entrepreneurs to learn more about managing their business efficiently [32]. Thus, the business plan emerges as a valuable learning tool $[20,32]$ that enables entrepreneurs to interpret information, adjust original plans, and make the right decisions in order to anticipate problems and opportunities $[6,14,24,33-35]$. Entrepreneurs who embrace this learning process and thus reflect thoroughly on their business project might improve their understanding of business dynamics, which could help them to anticipate changes and to act adequately. Therefore, the first objective of this study was to analyze whether the quality of a business plan subsequently enables entrepreneurs to monitor their business effectively during the first year after creating a business. To our knowledge, previous studies have not empirically investigated the link between the thorough reflection an entrepreneur makes, and its direct effect (i.e., does it truly support entrepreneurs to manage their business more effectively?). Therefore, we linked the business life cycle literature to the value of business planning. The business life cycle literature namely offers insights into the important and even vital planning needs during the start-up phase of a business, highlighting the potential value of business planning for starters [20].

An external accountant seems to be an important adviser in the start-up phase of a business, especially when a business plan is developed [23,36,37]. Accountants are highly trusted advisors [38] who possess specialist knowledge and skills [39] and are able to ensure that a business plan complies with legal requirements. Moreover, external accountants are also able to transcend the traditional role in which they offer compliance services [40,41]. Accountants are able to act as coaches who assist their client entrepreneurs during the start-up phase. They are able to complement key gaps in the entrepreneur's knowledge and skills in order to support the launch, survival, and growth of the business [42]. Developing and challenging the business plan, engaging in a thorough discussion of diverse aspects, and providing support to (re)structure ideas might help entrepreneurs to further enhance their proposed business activity and thus increase the quality of their business plan. This 
study elaborates on the role of external accountants in guiding (nascent) entrepreneurs when developing a business plan. The second objective was therefore to study if the advice of an external accountant supports entrepreneurs to develop a high-quality business plan (i.e., the extent to which entrepreneurs reflect thoroughly on diverse items of the business plan). Previous studies found that the advice provided by accountants is valuable for SMEs [43-45]. This paper focused on advice provided by accountants during the business planning stage, adding further insights to the existing literature. In particular, the guidance of accountants was studied in relation to the quality of a business plan, and its subsequent effectiveness for entrepreneurs.

This study was executed in the Belgian context, in which entrepreneurs are legally obliged to develop a financial plan when they establish a company with limited liability. This legal requirement should support entrepreneurs in (1) carefully estimating their (expected) turnover; (2) assessing the necessary capital and funding; (3) understanding and carefully evaluating the possibility of the company generating cash resources; and (4) making well-informed decisions [46,47]. By imposing a strict regulation, the government emphasizes the importance of this business plan and the underlying objective of reflecting consciously on uncertain aspects faced by (nascent) entrepreneurs. The ultimate goal is to support entrepreneurs in assessing their business project thoroughly.

Some entrepreneurs develop their business plan because of the legal obligation with which they need to comply. Another common reason to create a business plan is to obtain external financing. However, entrepreneurs might also aim to gain more insight into the feasibility of their business project and/or want to learn new things. Thus, entrepreneurs have very diverse underlying reasons for developing a business plan [8]. The self-determination theory (SDT) offers a framework to capture the motivational drivers of entrepreneurs to develop a business plan and its subsequent quality. SDT proposes a continuum ranging from "non-self-determined" or controlled motivation to "self-determined" or autonomous motivation [48-52]. Control-oriented individuals feel an external pressure to act, which typically leads to rather undesirable results [48,53]. Autonomously oriented individuals, in contrast, act because of an internal locus of control, which typically leads to more desirable outcomes $[48,53]$. SDT is "based on a multidimensional view of the concept of motivation that distinguishes the quantity, amount, or intensity of motivation from the quality or type of motivation" [53] (p. 671). This study aimed to gain a deeper understanding of the underlying motivation of entrepreneurs to develop a business plan. To our knowledge, the current literature does not link the underlying motivations of entrepreneurs to the quality of the developed business plan and the subsequent effectiveness. This underlying motivation could, however, add relevant insights to better understand the (perceived) value of a business plan. Therefore, this study linked the business planning literature with the theory of self-determination. The third objective of this study was thus to analyze if the type of motivation behind the development of a business plan is linked to the quality of said business plan.

The contributions of this article are threefold. First, the underlying reasons to develop a business plan were untangled, using the SDT framework. Four types of motivation were translated to the context of business planning for starters and investigated in relation to the perceived quality of the business plan, providing new insights into the existing literature. Second, this study addressed the quality of the business plan, as perceived by the entrepreneur, and investigated whether this quality is linked to entrepreneurial effectiveness during the first year after the start-up. The quality of the business plan was adapted to the specific context of a starter, capturing how intensively the starter has reflected on 22 topics, which are usually found in a business plan. The effectiveness was contextualized to starters, where short-term financial needs and sales figures need to be monitored in decision making to ensure the viability of the company. Third, as noted in [54], more insight is needed regarding the advice provided to entrepreneurs during the start-up phase of a business. While external accountants seem to be important advisers for starters, the exploration of their role in guiding these entrepreneurs is underdeveloped in 
the existing literature. This study aimed to contribute to this literature gap as it analyzed the role of external accountants in the development of a business plan.

The remainder of the article is structured as follows. In the next section, hypotheses are formulated based on a literature review. The methodology section describes the data collection, survey development, and variable measurement. Next, the descriptive statistics and results are illustrated. Then, the findings are discussed in relation to the theoretical background. Finally, conclusions and practical implications for external accountants and nascent entrepreneurs are formulated.

\section{Literature Review and Development of Hypotheses}

\subsection{Self-Determination Theory and the Development of a Business Plan}

Why do starters decide whether or not to engage in business planning? Several drivers may motivate (or demotivate) entrepreneurs to develop a business plan. For example, one might develop a business plan because it is legally required, while also wanting to gain more insight in the business project. However, some reasons will be more important factors in the entrepreneurs' motivation to develop a business plan than others. The SDT identifies a continuum of motivation, ranging from external to intrinsic motivation $[48,53,55]$. Four types of motivation are distinguished: External, introjected, identified, and intrinsic motivation [51]. These degrees differ in the extent to which external sources are internalized [49].

When someone is externally motivated to act, they typically set this behavior because of an external pressure. They might, for example, want to avoid punishment, to meet external expectations, and/or to obtain approval [51,53]. In a start-up context, in [8], the authors found that a formal business plan was mainly prepared when entrepreneurs needed to invest a large amount of money. In a similar vein, other studies have concluded that entrepreneurs seem to prepare a formal, written business plan only if they need to obtain external funding because potential investors seem to have specific requirements about the format of this business plan $[14,56]$. The development of a business plan is therefore often perceived as an obligation, instead of a valuable management instrument that enables entrepreneurs to make informed decisions [57]. These entrepreneurs experience an external pressure to prepare a business plan; translated to the start-up context, external motivation therefore means that entrepreneurs develop a business plan because it is (legally) required or because an investor expects them to do so.

However, pressure to act in a certain way does not always originate from an external source [51,53]. Individuals are also able to pressure themselves. In this event, their rationale to act is not entirely external, as they have partially internalized an external pressure. However, there is still some form of pressure present. Their motivation has not been fully accepted as being their own as the main driver still originates from external sources. Consequently, they deal with feelings of conflict $[53,58]$. This phenomenon is called introjected motivation [51,53]. For the business planning context, this means that entrepreneurs might develop a business plan because they would feel ashamed, guilty, or even anxious if they did not. They want others to perceive them as smart or as a good, capable entrepreneur and therefore develop a business plan.

The third type of motivation is called identified motivation [51,53]. These individuals do not experience the activity as intrinsically interesting, but they identify themselves with its value as it is consistent with their personal goals $[49,51,53]$. Translated to the business planning context, this means that some entrepreneurs develop a business plan mainly because they acknowledge the personal value of this activity. They want to learn new things, understand the content of the business plan, and gain insight into the feasibility of their business project.

Intrinsic motivation is the fourth type of motivation on this continuum [51,53]. These individuals are enthusiastic to engage in this activity and perceive it as fun [51]. They act out of curiosity and personal interest. Moreover, the activity itself creates a feeling of spontaneous satisfaction [49], thus, their motivation is entirely self-determined [53]. Translated 
to the business planning context, this means that intrinsically motivated entrepreneurs develop a business plan because they are excited and perceive the activity of business planning as fun.

External and introjected motivation are two types of motivation that are characterized by a feeling of pressure, an external locus of control, which typically leads to rather undesirable results $[49,51,53,59]$. Previous studies in various domains have found, for example, that they lead to the application of maladaptive coping strategies [58], poor concentration and time management as well as anxiety [60]. Thus, in general, pressuring individuals externally with rewards if a certain target is achieved, or threatening them with punishments if not as well as more subtle pressures such as feelings of guilt or shame, typically lead to less desirable outcomes [53]. Identified and intrinsic motivation are characterized by feelings of choice and an internal locus of control, and typically lead to rather desirable outcomes $[49,51,53,59,61]$. Previous studies have found, for example, that the latter types of motivation are related to better time management [60], more effort, determination and will [58], greater intention to persist [62], and greater effective perseverance [63]. It is not necessary for individuals to process along the diverse motivational types as internalizing external regulation is possible at any point on the continuum [51].

Based on the SDT, it is hypothesized that external and introjected motivation are negatively related to the quality of a business plan. In other words, entrepreneurs with high external or high introjected motivation do not develop a high-quality business plan. They develop their business plan because of an external pressure and are consequently expected to reflect less thoroughly on the diverse topics of the said business plan. Entrepreneurs with high identified or high intrinsic motivation are, in contrast, expected to develop a high-quality business plan. Therefore, we propose the following hypotheses.

Hypothesis $1 \mathbf{a} / \mathbf{b}$. External and introjected motivation to develop a business plan are negatively related to the quality of said business plan.

Hypothesis 1c/d. Identified and intrinsic motivation to develop a business plan are positively related to the quality of said business plan.

\subsection{The Role of the External Accountant as a Business Adviser}

As it is quite impossible to be personally specialized in every entrepreneurial domain, (nascent) entrepreneurs often seek advice from external service providers such as assistance agencies, business networks, and private advisers [64,65]. In [66], the authors found that entrepreneurs who sought support when facing complex situations were most likely to be successful in the long run. They stated that "advice seeking is smart business behavior" (p. 144). In [34], the authors further suggested that it would be valuable for entrepreneurs to seek advice early in the start-up phase as "much of the support valued and sought by entrepreneurs is likely to be beneficial and occasionally necessary in maximizing the effectiveness of the business planning process" (p. 637). Furthermore, external advice is assumed to enhance entrepreneurial learning and to improve capabilities for future decision making $[39,67]$. The external accountant seems to be an important adviser in the start-up phase of a business, especially when a business plan is being prepared $[20,23,36,37,68]$. The technical complexity of the financial plan, for example, will often require recourse to a practitioner. Many entrepreneurs thus rely on their external accountant to gain access to specialized, complementary knowledge [39,69].

Furthermore, the objective second opinion of an expert such as an external accountant might be enlightening as they might identify items that need adjustment $[19,35]$. The development of a realistic and complete business plan requires a thorough and careful consideration of very diverse aspects of the business project. A competent external accountant can assist entrepreneurs in preparing their business plan and can minimize the likelihood that it will be inaccurate and/or incomplete [70]. They are able to fill knowledge gaps and to help entrepreneurs to process information and identify opportunities and 
threats $[54,70,71]$. However, in [31], the authors found that only $23 \%$ of entrepreneurs asked an external accountant for advice before starting their business, and only half used an external accountant after starting their business. In [72], the authors stated that entrepreneurs might undervalue these advisory services when they are not familiar with the use of external support [23]. Accountants are not merely "bean counters", but are able to act as coaches or partners that provide tailor-made business advice [38-40,67]. Therefore, it is important that entrepreneurs are aware of the services that external accountants are able to provide, but it might be even more important for accountants to address their (potential) added value and highlight the positive impact their services will—or might-have in the future $[42,73,74]$. The motivational profile of entrepreneurs to develop a business plan is expected to impact their reliance on the advice of an external accountant. Some entrepreneurs will experience an external pressure to develop a business plan and are presumed to focus on complying with the technical aspects of a business plan. These control-oriented entrepreneurs will mainly rely on the advice of an external accountant to meet the legal requirements and/or expectations of third parties. Thus, entrepreneurs who are more control-oriented are expected to use the advice of an external accountant to develop a business plan. Therefore, we hypothesize the following:

Hypothesis $2 \mathbf{a} / \mathbf{b}$. Entrepreneurs with high external/introjected motivation to develop a business plan are more likely to use the advice of an external accountant than entrepreneurs with low external/introjected motivation.

Other entrepreneurs will experience an internal drive to develop their business plan. They want to learn new things, gain more insight in their business project, and/or have a personal interest in business planning. These entrepreneurs might, however, not necessarily ask their accountant for advice as they often mainly consider them to provide compliance services. Generally, entrepreneurs seem to undervalue the advisory services of accountants, and might consequently not rely on their external accountant to support them in developing their business plan. They are presumed to focus on their personal growth and interests, which is not always directly linked to the service provision of accountants. These entrepreneurs are consequently not expected to rely on the advice of an external accountant. Therefore, we hypothesize the following:

Hypothesis 2c/d. Entrepreneurs with high identified/intrinsic motivation to develop a business plan are less likely to use the advice of an external accountant than entrepreneurs with low identified/intrinsic motivation.

Business advisers can facilitate and enhance the knowledge of their clients by steering them in the business planning process [13,75]. It is thus essential for entrepreneurs to collect information and align their findings with their adviser, who functions as a sounding board and evaluates and refines their preparation. This iterative process allows entrepreneurs to deepen their understanding and to gain knowledge about their entrepreneurial project $[65,70]$. A prerequisite for successful cooperation with their external accountant is that entrepreneurs need to understand the figures and the explanation of the external accountant in order to benefit from the business plan and to monitor the business effectively $[23,27]$. Therefore, external accountants need to educate their clients, explain the accounting information in an accessible manner, and enable them to use this information in their decision-making process [42]. SDT states that individuals possess a strong, natural propensity for personal development, an inner driver to function optimally, and a strong will to achieve their goal [76] (i.e., the development of a business plan that enables entrepreneurs to manage their business effectively). External accountants thus face the challenge of empowering their client entrepreneurs in the development of this business plan. This might be the meaningful rationale needed to acknowledge the potential value of a business plan. Entrepreneurs who are heavily involved in the business planning process create the opportunity to internalize knowledge from the external accountant. This 
stimulates a constructive dialog that enables them to reflect thoroughly on their business project and enhances their capability to process and use relevant information [70,75].

Hypothesis 3. Advice provided by an external accountant is positively related to the quality of a business plan.

Furthermore, in [43], the authors found a positive relationship between the frequency of business advice provided by an external accountant and the survival of a business. External advisers should be able to fully understand their client entrepreneur [66,77], as "understanding the individual entrepreneur becomes as crucial as understanding the business" [78] (p. 4). Therefore, an external accountant should function as a peer-or a coach - who listens and is able to understand the client's business needs and to subsequently act proactively $[70,79]$. Tailor-made advice is indispensable; "one size fits all" approaches will not work $[32,80,81]$. As Catto [42] pointed out, "the success of external advisers depends on the advisers' ability to obtain knowledge of the business and complement tacit knowledge with technical knowledge" (p. 64). Frequent meetings should enable external accountants to fulfill their role as a valuable partner. Timely feedback and an intense corporation might increase the quality of a business plan [5,32,82]. Thus, developing a high quality business plan requires an intense, thoughtful, and iterative process [65,70]. Frequent meetings and timely feedback offer the opportunity to reflect and to adjust the original plan when needed $[6,14,24,33-35]$. An external accountant is able to guide entrepreneurs during this process, step-by-step, and support them in understanding the dynamics of their business project $[66,77]$. A high frequency of meetings is consequently expected to benefit the quality of the business plan. Therefore, we hypothesize the following:

Hypothesis 4. The frequency of advice provided by an external accountant is positively linked to the quality of a business plan.

\subsection{Business Planning and Effectiveness as a Planning Benefit}

In [83], the authors stated that "the value of planning is driven by the possibility of evaluating alternative actions and being able to improve strategies" (p. 385). Formal planning might be a necessary prerequisite to enable an entrepreneur to make optimal decisions and to support improvisational activities when needed $[9,14,35,84,85]$. The process of business planning seems essential rather than the product (i.e., the business plan itself). In [86], the authors emphasized that it is not useful to develop a "finished perfect business plan". A business plan is never finished, but its development should enable entrepreneurs to make well-informed decisions based on imperfect information and should help them to face complexity and uncertainty [70,86]. It is essential to acquire the capability to anticipate unexpected events or evolutions [87-89]. As stated in [28], "an adaptive business planning process, embedded in a founding environment that determines which rationale should govern the planning activities" (p. 783). The business planning process is expected to support entrepreneurs in understanding the business environment and dynamics. Thus, in order to benefit from business planning, entrepreneurs should not perceive the business plan as a "static document", but as an instrument to monitor the overall evolution of a company and the achievement and adjustment of goals [19,22] In this respect, the business plan becomes a management tool to assess the actual figures relative to the projected figures and to continuously monitor the overall viability of a business $[10,36,90]$. Consequently, developing a business plan is expected to improve entrepreneurial effectiveness $[9,19,21]$.

Developing a realistic and complete business plan requires an entrepreneur to make a variety of assumptions and to reflect thoroughly on diverse relevant aspects of the business project [19]. Thus, it seems that the business plan will be an effective management instrument only if the entrepreneur develops a high-quality business plan. Furthermore, 
as stated in [91], "the savvy entrepreneur executes a plan" (p. 593). In this manner, the business plan becomes a learning tool—a management instrument that supports the entrepreneur in managing the business more effectively [6,32]. Therefore, the following hypothesis was formulated:

Hypothesis 5. The quality of a business plan is positively linked to entrepreneurial effectiveness during the first year after the start of the business.

Figure 1 provides an overview of the hypotheses.

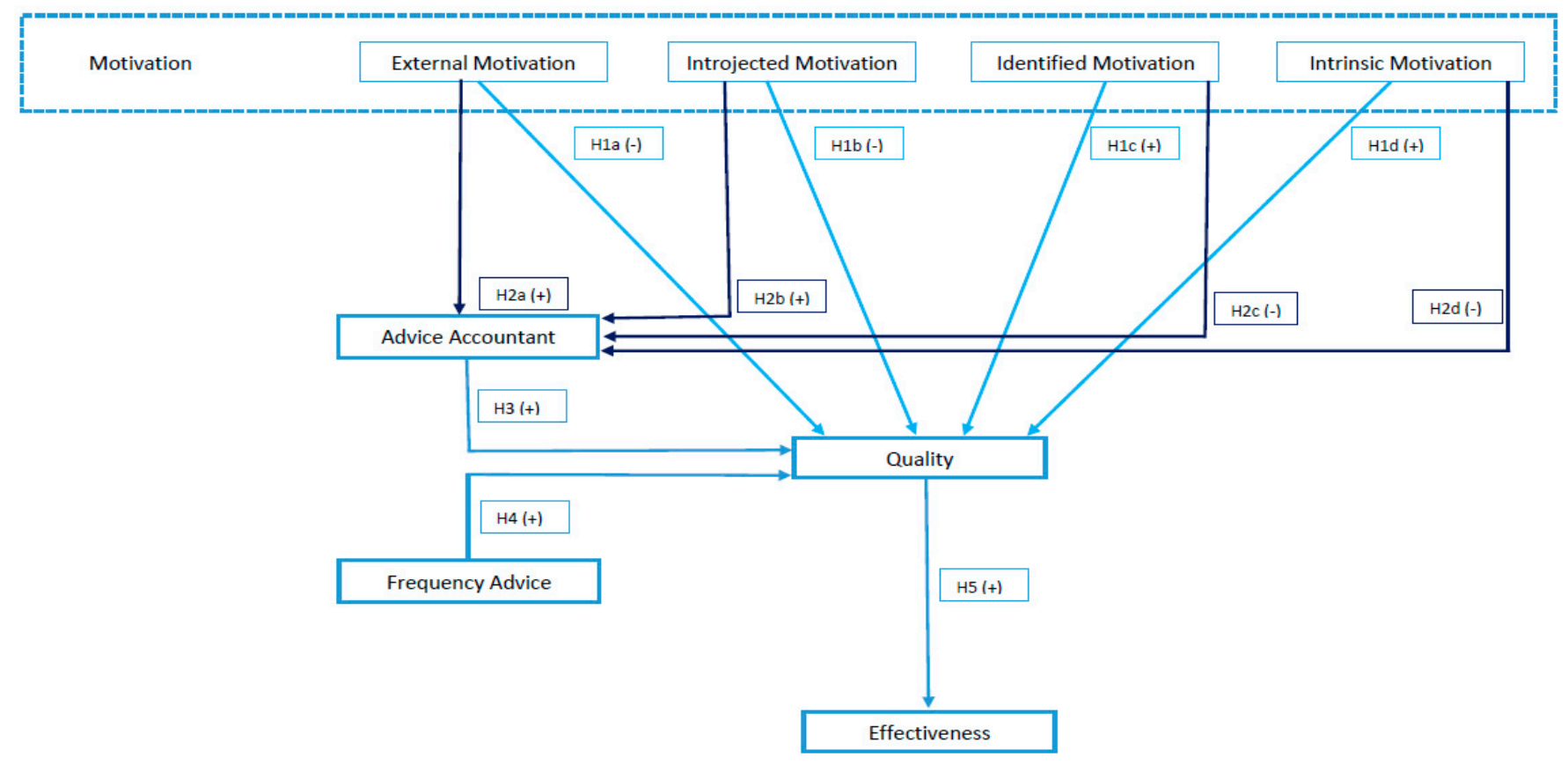

Figure 1. Overview of the hypotheses.

\section{Methodology}

\subsection{Data Collection}

3.1.1. Preliminary Interviews

First, preliminary interviews were held with several important actors in the business planning context. In total, 10 entrepreneurs (entrepreneurs who founded their own, ongoing business a maximum of three years prior to the interview), four representatives of diverse business organizations (Agentschap Innoveren en Ondernemen, Startersfabriek, Starterslabo, and Unizo), 10 external accountants, three representatives of accounting and tax organizations, five bankers, five solicitors, five lawyers, and two judges were interviewed. The interviews comprised four main themes:

(1) How do entrepreneurs decide whether to develop a business plan?

(2) Which topics are important to consider carefully when developing a business plan?

(3) When is a business plan an effective tool for entrepreneurs?

(4) Which role should service providers-particularly external accountants—play in guiding entrepreneurs during their start-up process?

These interviews were held in September 2016-February 2017; they lasted, on average, an hour and a half and took place at the premises of the relevant interviewee. Afterward, the interviews were transcribed and analyzed. The different perspectives of the interviewees on the four themes were enlightening; lawyers, for example, highlighted the importance of compliance with regulations, while external accountants stressed the importance of funding and the feasibility of a business project. These intensive consultations and different 
perspectives guaranteed a thorough understanding of the four themes above-mentioned and provided valuable information to develop the measures and the survey instrument.

\subsubsection{Online Survey}

The hypotheses were tested using an online survey for starters who prepared a business plan. Experts from the preliminary interviews were intensively consulted to translate the measures to the context of business planning and to develop the survey instrument. Their feedback on intermediate versions of the survey instrument was very valuable to further improve the questionnaire and ensured an accurate translation of their answers from the preliminary interviews (March 2017-July 2018). The developed survey was pretested by seven starters (different from those of the preliminary interviews) to ensure that all questions were clear and easy to answer. In Belgium, there is no available official list of starters who have developed a business plan (with/without the advice of an external accountant). Therefore, a purposive sampling technique was applied [92]. Starters complying with the following selection criteria were targeted: Small- or medium-sized enterprises in the Flemish region that were founded since January 2017. The survey was administered by Qualtrics and sent in August 2018 via newsletters and the websites of various Belgian business organizations, their Facebook pages, and LinkedIn profiles as well as via the social network of external accountants, their business associations, and educational institutions. Our call to participate in this research project was also further shared by others via social media, encouraging starters in their network to participate in the survey. This virtual snowball sampling method has been proven to be effective in previous studies $[93,94]$ and has successfully been applied to collect data from businesses $[95,96]$. However, starters were quite reluctant to cooperate because of their busy schedule and the sensitive information that they would have to share (information concerning their business project and financial situation). The survey for this sample was closed in February 2019, meaning that the respondents managed their new business for a maximum period of 23 months. Consequently, it was reasonably assumed that respondents would be able to recall the development of their business plan and the support/advice they relied on with relative ease and accuracy [34].

Despite all efforts, only 163 responses were collected. To further increase the number of responses, a second wave of data collection was initiated. Bisnode-a professional data company that has the largest reference database of companies in Belgium-provided 13,860 personal email addresses of starters that complied with the predefined selection criteria. The survey for this second sample was sent in February 2019. Two reminders were sent after four and six weeks, respectively. In total, 283 starters completed the questionnaire. Previous studies related to this topic and performed in the Belgian context, showed a comparable number of responses $[69,97]$. The two waves of data collection were analyzed, but no differences were found in the answers from these two samples.

The sample population consisted of $56.3 \%$ men and $43.7 \%$ women. In total, $44.3 \%$ of the respondents had more than five years of experience in the sector before launching their own business. Moreover, $34.5 \%$ of them had already launched another business in the past and thus had already gained experience in entrepreneurship. Furthermore, the vast majority of the respondents $(73.2 \%)$ had a degree in higher education. However, only $29.3 \%$ of the respondents had a degree in business economics.

\subsection{Variables}

\subsubsection{Motivation to Develop a Business Plan}

SDT has extensively been studied in various domains such as health care, sports, work, and education $[53,55,58,60,98]$. The drivers leading entrepreneurs to develop a business plan were assessed with a modified academic scale for self-regulation, based on the work of [58]. The existing literature and preliminary interviews (see Section 3.1.1) provided thorough insights to translate this measurement instrument for motivation to the context of business planning. As a result, four motivational profiles for developing a business 
plan were created. In analogy with the original scale $[53,58]$, external motivation refers to the fulfillment of legal requirements, rule compliance, or the expectations of third parties. For the business planning context, this means that these entrepreneurs developed a business plan mainly because they were (or felt) obliged to do so. Consequently, they experienced a feeling of pressure. Entrepreneurs often develop a business plan to meet the external expectations from third parties such as the government, investors, and service providers $[10,16,56]$. The second type, introjected motivation, was framed in terms of internalized pressures such as behavior undertaken to avoid feelings of guilt or shame. During the preliminary interviews, some entrepreneurs stated that their business plan was an instrument used to gain (symbolic) legitimacy for their business project as they wanted to convince others that they were a good, capable, intelligent, and committed entrepreneur. Their business plan was an important instrument to obtain approval and appreciation from others. Therefore, one item was added to the original scale: "Because others would appreciate me as an entrepreneur". The third type of motivation, identified motivation, was captured by reasons that were related to personal goals or values. In a business planning context, this meant that some entrepreneurs developed their business plan because they truly wanted to understand the content of this potentially valuable management instrument and sought a thorough insight into the feasibility of their business project. In [32], the authors found that entrepreneurs were more capable of managing their business efficiently if they perceived their business plan as a useful guideline for decision making. Consequently, two items were added to the original scale: "Because I really wanted to understand the content of the business plan" and "Because I wanted to gain insight into the feasibility of my business project". The fourth type of motivation, intrinsic motivation, refers to entrepreneurs who develop a business plan because they experience it as a fun and exciting thing to do (later on, two items were deleted because they were highly loaded regarding the construct of identified motivation: "I developed my business plan because ... (1) I was highly interested in developing a business plan and (2) I enjoyed developing a business plan"). A summary of the items is given in Table 1 (variable measurement). The respondents were asked to score all items of motivation in a business planning context on a five-point Likert scale. A principal component analysis (PCA) was conducted on these items. Factor analysis provided four factors, confirming the motivational profiles validated in previous studies [53,58]. The Kaiser-Meyer-Olkin and Bartlett's tests illustrated that the data were adequate for factor analysis. The average of the respective items was calculated per respondent to obtain a measurement for each motivational profile (on a scale of 1-5). Details on the measurement instrument are presented in Table 1.

\subsubsection{Quality of a Business Plan}

In order to reveal the potential value of the business plan, entrepreneurs need to reflect thoroughly on all relevant topics contained in the business plan $[13,86]$. In other words, it is important to thoroughly reflect on every aspect of the plan to develop a sound business plan that offers support to manage the business more effectively. Therefore, the more you reflect on each item, the higher the quality of the plan will be. Furthermore, business plans traditionally contain various items that are summarized in a quite standard format and usually subdivided into three main categories referring to the economic, organizational, and financial viability of a company $[7,11,19,86]$. Based on the existing literature, the preliminary interviews (see Section 3.1.1), and document analysis (business plans provided by entrepreneurs during preliminary interviews), a list of relevant items was created. To achieve consensus on the topics that were important to consider carefully when developing a business plan, this list of items was further discussed with experts (five external accountants, five entrepreneurs, and three lecturers in entrepreneurship). In total, 22 items were included in the measurement instrument. In order to capture the quality of a business plan, respondents rated these 22 items on a scale of $1-5$ ( $1=$ not important at all; 
$5=$ very important). The average of these items was calculated per respondent. Details of this measurement instrument are summarized in Table 1.

Table 1. Variable measurement.

\begin{tabular}{|c|c|c|}
\hline Variable Name & Measurement Scale & $\begin{array}{l}\text { Factor } \\
\text { Loadings }\end{array}$ \\
\hline Motivation $(1)$ & $\begin{array}{l}\text { Indicate how important the following reasons were for writing a business plan when } \\
\text { preparing the launch of your business? Means based on the following items: } \\
\text { I developed my business plan because ... ( } 1 \text { = not important at all; } 5 \text { = very important })\end{array}$ & \\
\hline \multirow{4}{*}{$\begin{array}{l}\text { External_Motivation } \\
\text { Kaiser-Meyer-Olkin }=0.683 \\
\text { Bartlett's test }=0.000 \\
\text { Cronbach's alpha }=0.735\end{array}$} & $\begin{array}{l}\text { 1. I was supposed to do so (developing a business plan when launching a new } \\
\text { business; that is how it should be). }\end{array}$ & 0.556 \\
\hline & $\begin{array}{l}\text { 2. The government forced me to do so (developing a business plan was } \\
\text { a legal obligation). }\end{array}$ & 0.733 \\
\hline & $\begin{array}{l}\text { 3. Others (external accountant, banker/investor, consultant) obliged me to do so (e.g., } \\
\text { developing a business plan was a prerequisite to obtain financing). }\end{array}$ & 0.838 \\
\hline & 4. Others (government, external accountant, banker) expected me to do so. & 0.843 \\
\hline \multirow{5}{*}{$\begin{array}{l}\text { Introjected_Motivation } \\
\text { Kaiser-Meyer-Olkin }=0.774 \\
\text { Bartlett's test }=0.000 \\
\text { Cronbach's alpha }=0.879\end{array}$} & 1. Others would perceive me as a committed and engaged entrepreneur. & 0.841 \\
\hline & 2. I would feel guilty if I did not develop a business plan. & 0.758 \\
\hline & 3. I would feel ashamed if I did not develop a business plan. & 0.806 \\
\hline & 4. Others would perceive me as an intelligent, capable entrepreneur. & 0.864 \\
\hline & 5. Others would appreciate me as an entrepreneur. * & 0.841 \\
\hline \multirow{6}{*}{$\begin{array}{l}\text { Identified_Motivation } \\
\text { Kaiser-Meyer-Olkin }=0.873 \\
\text { Bartlett's test }=0.000 \\
\text { Cronbach's alpha }=0.902\end{array}$} & 1. I really wanted to understand the content of the business plan. * & 0.863 \\
\hline & 2. I wanted to learn new things. & 0.791 \\
\hline & 3. I wanted to gain insight into the feasibility of my business project. * & 0.840 \\
\hline & $\begin{array}{l}\text { 4. For me, it was personally important to carefully reflect on the commercial, legal, } \\
\text { and financial aspects of my project before launching my business. }\end{array}$ & 0.830 \\
\hline & $\begin{array}{l}\text { 5. This represented a meaningful choice to me and was congruent with } \\
\text { my personal values. }\end{array}$ & 0.806 \\
\hline & $\begin{array}{l}\text { 6. This was an important life goal for me. Launching a new business successfully } \\
\text { requires careful consideration. A business plan is a necessary tool to monitor the } \\
\text { figures during the first months after start-up. }\end{array}$ & 0.804 \\
\hline \multirow{2}{*}{$\begin{array}{l}\text { Intrinsic_Motivation } \\
\text { Kaiser-Meyer-Olkin }=0.500 \\
\text { Bartlett's test }=0.000 \\
\text { Cronbach's alpha }=0.919\end{array}$} & 1. It was fun to develop a business plan. & 0.962 \\
\hline & 2. It was exciting to develop a business plan. & 0.962 \\
\hline Quality_Business_Plan & \multicolumn{2}{|c|}{$\begin{array}{l}\text { How important was it for you as an entrepreneur to reflect thoroughly on the following items of a } \\
\text { business plan ( } 1 \text { = not important at all; } 5 \text { = very important)? The quality was calculated as the } \\
\text { means of } 22 \text { different subjects captured in a business plan (sector analysis; customer analysis; } \\
\text { market analysis, including analysis of competitors; pricing policy; mission and vision; competencies } \\
\text { (of yourself and, if applicable, the competences of your business partner(s)); personnel (recruitment, } \\
\text { human resources); legal form of the business; formation expenses; necessary investments; } \\
\text { inventories; payment conditions and receivables from customers; value added tax (VAT); } \\
\text { financing/(extra) funding; turnover; costs; monthly income for the entrepreneur; margins; } \\
\text { break-even; financial analysis (liquidity, profitability, solvency, cash flow); cash planning; taxes } \\
\text { (e.g., income taxes)). }\end{array}$} \\
\hline
\end{tabular}


Table 1. Cont.

\begin{tabular}{|c|c|c|}
\hline Variable Name & Measurement Scale & $\begin{array}{c}\text { Factor } \\
\text { Loadings }\end{array}$ \\
\hline \multirow{6}{*}{$\begin{array}{l}\text { Effectiveness } \\
\text { Kaiser-Meyer-Olkin }=0.854 \\
\text { Bartlett's test }=0.000 \\
\text { Cronbach's alpha }=0.874\end{array}$} & $\begin{array}{l}\text { During the first year after the start-up of your business, to what extent was the } \\
\text { business plan important to... ( } 1 \text { = not important at all; } 5=\text { very important })\end{array}$ & \\
\hline & 1. Monitor financial needs (e.g., extra funding). & 0.795 \\
\hline & $\begin{array}{l}\text { 2. Monitor (and understand the development of) the manager's income } \\
\text { (allowance/fee) from the company. }\end{array}$ & 0.773 \\
\hline & 3. Monitor sales figures. & 0.813 \\
\hline & 4. Prevent liquidity shortage. & 0.877 \\
\hline & 5. Make decisions to ensure the viability of the company. & 0.815 \\
\hline Advice_Accountant & $\begin{array}{l}\text { Before launching my business, } \ldots(0=\mathrm{I} \text { did not rely on an external accountant for } \\
\text { advice concerning the development of my business plan; } 1=\mathrm{I} \text { relied on an external } \\
\text { accountant for advice concerning the development of my business plan) }\end{array}$ & \\
\hline Frequency_Advice & $\begin{array}{l}\text { How many times did you consult your external accountant concerning the } \\
\text { development of your business plan before actually launching your business? }\end{array}$ & \\
\hline Experience & $\begin{array}{l}\text { Was the establishment of this new company a conversion of an existing legal entity? } \\
(0=\text { no; } 1=\text { yes })\end{array}$ & \\
\hline $\begin{array}{l}\text { Business_Management_ } \\
\text { Certificate }\end{array}$ & $\begin{array}{l}\text { Did you obtain a business management certificate before launching your business? } \\
(0=\text { no; } 1=\text { yes })\end{array}$ & \\
\hline
\end{tabular}

(1) Measurement scale based on $[53,58]$ and translated to the context of business planning. The Cronbach's alpha of the original scale is as follows: External motivation $=0.77$; introjected motivation $=0.69$; identified motivation $=0.79$; intrinsic motivation $=0.89$. ${ }^{*}$ Items added to the original scale, based on preliminary interviews.

\subsubsection{Effectiveness of a Business Plan}

The concept of effectiveness originates from organization theory [99]. In [99], the authors pointed out that there was little agreement on the criteria that should be used to capture "effectiveness". Consequently, there is no general definition of effectiveness as such. In [100], the author defined it as "human judgments about the desirability of the outcomes of organizational performance" (p. 614). Furthermore, the author stated that "theoretically, there are a potentially infinite number of perspectives about the desired outcome on which these judgments could be based. As a result, there are a potentially infinite number of effectiveness models" (p. 614). Several researchers have argued that the most relevant measure of effectiveness would be a function of how well the formal planning capability was able to meet the specific planning needs [101].

The business life cycle literature offers insights into the important and even vital planning needs during the start-up phase of a business, highlighting the potential value of business planning for starters [20]. In [102], the authors developed a business life cycle framework that consists of five stages: the existence, survival, success, take-off, and resource maturity of businesses. The first stage, "existence", concerns the start-up phase of a business. During this stage, monitoring five crucial key indicators seems an important tool to support entrepreneurs in anticipating "the unexpected" $[20,86]$ and ensuring the survival of a company $[6,17,20,86]$. First, an entrepreneur should build a solid client base that results in sufficient sales $[6,20,102-105]$. An entrepreneur should also be able to monitor the sales figures and take action when they realize their target will not be met [106]. Second, it is extremely important that entrepreneurs prevent liquidity shortages $[5,20,102,104]$. Liquidity shortages are one of the most common reasons for the failure of young firms [6]; thus, understanding and rationally estimating the possibilities of a business to generate cash is very important. Third, monitoring financial needs is crucial [107]. Entrepreneurs should build a strong financial capability, focusing on the efficient utilization of available resources [91]. When extra funding is needed, entrepreneurs have to be able to anticipate and monitor this evolution in order to provide extra resources 
on time [91]. Fourth, it is important that an entrepreneur is capable of matching their personal and business goals. A business should, for example, provide an income or fee to the owner/manager (in the long- or short-term). This is not always possible during the first years; however, at some point in time, the business should be able to deliver an income for the owner/manager. It is therefore important that owners/managers understand the dynamics between these business and personal affairs [103]. Finally, entrepreneurs need to gather relevant information on which their well-informed decisions should be based. Careful consideration of the diverse aspects of the business plan helps entrepreneurs to reduce risks and to ensure the survival of the business $[5,18,32,89]$. Entrepreneurs should be able to gather and interpret relevant information correctly and to subsequently make informed decisions [32]. The business has to prove its viability in order to reach the second stage of the business life cycle: Success [20]. In summary, effectiveness is measured in terms of the extent to which a business plan enables an entrepreneur to monitor key indicators during the first year after launching the business. Monitoring these five items is important to anticipate "the unexpected" and to subsequently guarantee the viability of the business.

These key indicators were further thoroughly discussed with the experts (see Section 3.2.2: Five external accountants, five entrepreneurs, and three lecturers in entrepreneurship) to gain confirmation of the measurement of the effectiveness of a business plan. In order to capture the effectiveness of a business plan, respondents were asked how important their business plan was during the first year after the start-up and to rate the five identified crucial items on a five-point scale ( $1=$ not important at all; $5=$ very important). A PCA was conducted for these five items. Factor analysis provided one factor, with factor loadings all above 0.77 (see Table 1). Kaiser-Meyer-Olkin (0.854) and Bartlett's tests (0.000) illustrated that the data were adequate for factor analysis. The analysis showed a Cronbach's alpha of 0.874; the Cronbach's alpha did not improve when deleting an item. The average of these items was calculated for each respondent. Details on the items of the applied measure of effectiveness are summarized in Table 1.

\subsubsection{Role of the External Accountant}

The advice obtained from an external accountant was measured as follows: Entrepreneurs were asked in the survey to indicate whether or not they relied on an external accountant for advice concerning the development of the business plan before launching their business. The frequency of advice was measured in terms of how many times they consulted their external accountant concerning the development of their business plan before actually launching their business.

\subsubsection{Control Variables}

Two control variables were taken into account as these were strongly linked to the Belgian context in which the research was executed (survey). The control variable of "experience" was a dummy variable that showed whether the establishment of the new company was a conversion of an existing legal entity (e.g., sole proprietorship). When the official establishment of a new business was the result of a conversion, the entrepreneur could rely on historical data to develop the business plan, representing, of course, a very different situation than for brand new business projects. Therefore, it was important to include this control variable. Second, we controlled for a "Business Management Certificate"; Belgian entrepreneurs are strongly encouraged to take a course in business administration before launching a business. The control variable of the "Business Management Certificate" indicated whether the respondent had obtained a business management certificate before launching their business. The measures are summarized and explained in Table 1.

\section{Results}

\subsection{Descriptive Statistics}

The descriptive statistics are shown in Table 2. The different types of motivation were measured on a scale of $1-5$. The means of external motivation $(2.64$, standard deviation $=1.09)$ 
and introjected motivation $(2.07$, standard deviation $=1.08)$ were rather low. Identified and intrinsic motivation showed slightly higher means of 3.71 (standard deviation $=1.08$ ) and 3.03 (standard deviation $=1.40$ ), respectively. On average, $79 \%$ of the respondents used the advice of an external accountant to develop their business plan before launching their business. The frequency of advice provided by the external accountant ranged from 1 to 100. On average, the external accountant was consulted almost five times to develop the business plan before actually launching a business (standard deviation $=8.75$ ). Furthermore, the mean for the quality of the business plan was 3.26 on a scale of $1-5$ (standard deviation $=0.79$ ). Effectiveness was also measured on a scale of 1-5, with 2.85 as the average score (standard deviation $=1.23$ ). Moreover, approximately $16 \%$ of the respondents went through a conversion (standard deviation $=0.36$ ) and more than half of the respondents obtained a business management certificate (51\%). The data showed missing values, which explains the different numbers of observations. In order to deal with these missing values, cases were deleted listwise when performing the different analyses.

Table 2. Descriptive statistics.

\begin{tabular}{lccccc}
\hline & $N$ & Min. & Max. & Mean & SD \\
\hline External_Motivation & 283 & 1 & 5 & 2.64 & 1.09 \\
Introjected_Motivation & 283 & 1 & 5 & 2.07 & 1.08 \\
Identified_Motivation & 283 & 1 & 5 & 3.71 & 1.08 \\
Intrinsic_Motivation & 283 & 1 & 5 & 3.03 & 1.40 \\
\hline Advice_Accountant & 283 & 0 & 1 & 0.79 & 0.407 \\
\hline Quality_Business_Plan & 254 & 1 & 5 & 3.26 & 0.79 \\
\hline Effectiveness & 235 & 1 & 5 & 2.85 & 1.23 \\
\hline Frequency_Advice & 224 & 1 & 100 & 4.68 & 8.75 \\
\hline Experience & 283 & 0 & 1 & 0.16 & 0.36 \\
\hline Business_Management_Certificate & 283 & 0 & 1 & 0.51 & 0.50 \\
\hline
\end{tabular}

Table 3 presents a correlation table. Introjected, identified, and intrinsic motivation were significantly and positively correlated with the quality of the business plan. The correlation table further shows that external motivation was significantly and positively related to the use of an external accountant. In addition, the advice of the external accountant and the frequency of this advice were significantly and positively correlated with the quality of the business plan. The quality of the business plan, in turn, was significantly and positively correlated with effectiveness.

Table 3. Correlations.

\begin{tabular}{|c|c|c|c|c|c|c|c|c|c|c|}
\hline & 1 & 2 & 3 & 4 & 5 & 6 & 7 & 8 & 9 & 10 \\
\hline 1. External_Motivation & 1 & & & & & & & & & \\
\hline 2. Introjected_Motivation & 0.042 & 1 & & & & & & & & \\
\hline 3. Identified_Motivation & $-0.280 * *$ & $0.344^{* *}$ & 1 & & & & & & & \\
\hline 4. Intrinsic_Motivation & $-0.341 * *$ & $0.306^{* *}$ & $0.601 * *$ & 1 & & & & & & \\
\hline 5. Advice_Accountant & $0.240^{* *}$ & 0.005 & 0.020 & -0.047 & 1 & & & & & \\
\hline 6. Quality_Business_Plan & -0.053 & $0.339 * *$ & $0.564^{* *}$ & $0.365^{* *}$ & $0.186^{* *}$ & 1 & & & & \\
\hline 7. Effectiveness & $-0.154 *$ & $0.303^{* *}$ & $0.451 * *$ & $0.351^{* *}$ & 0.119 & $0.598^{* *}$ & 1 & & & \\
\hline 8. Frequency_Advice & 0.005 & -0.039 & 0.051 & 0.038 & c. & $0.142 *$ & 0.060 & 1 & & \\
\hline 9. Experience & $0.170 * *$ & 0.001 & -0.071 & -0.112 & $0.148 *$ & 0.015 & 0.042 & $0.131 *$ & 1 & \\
\hline 10. Business_Management_Certificate & -0.066 & -0.001 & 0.032 & 0.041 & -0.034 & $0.194 * *$ & 0.089 & -0.040 & -0.047 & 1 \\
\hline
\end{tabular}

Correlation is significant: ${ }^{* *} p<0.01,{ }^{*} p<0.05$; c., cannot be computed because at least one of the variables is constant. 


\subsection{Hypothesis Testing}

The results of the different regression analyses are shown in Table 4. Hypothesis 1c was supported by the data (model 1), as identified motivation was significantly and positively related to the quality of the business plan $(p<0.001)$. Entrepreneurs with identified motivation developed a business plan because they wanted to learn new things, understand the content of the business plan, and gain insight into the feasibility of their project. This was congruent with their personal values, which motivated them to develop a high-quality business plan. Hypothesis $1 \mathrm{~b}$ was rejected, as the results indicated that introjected motivation was also significantly and positively related to the quality of the business plan $(p=0.003)$, whereas we expected a negative effect. Entrepreneurs with an introjected motivation developed a high-quality business plan, mainly because they wanted others to perceive them as a committed entrepreneur. They were looking for appreciation, for the approval of others, and for recognition that they were an intelligent, capable entrepreneur. Moreover, they would have felt guilty or ashamed if they had not reflected thoroughly on their business project. Thus, in order to avoid these feelings and gain the approval of others, these entrepreneurs developed a high-quality business plan. Surprisingly, the analysis did not confirm Hypothesis 1d. We found no evidence for the expected positive relationship between intrinsic motivation and the quality of the business plan.

Table 4. Hypothesis testing.

\begin{tabular}{|c|c|c|c|c|}
\hline Variables & $\begin{array}{c}\text { Model 1 } \\
\text { Dependent Variable: } \\
\text { Quality_Business_Plan (a) }\end{array}$ & $\begin{array}{c}\text { Model } 2 \\
\text { Dependent Variable: } \\
\text { Advice_Accountant } \\
\text { (b) }\end{array}$ & $\begin{array}{c}\text { Model 3 } \\
\text { Dependent Variable: } \\
\text { Quality_Business_Plan (a) }\end{array}$ & $\begin{array}{c}\text { Model } 4 \\
\text { Dependent Variable: } \\
\text { Effectiveness }{ }^{(a)}\end{array}$ \\
\hline External_Motivation & $\begin{array}{c}0.033 \\
(0.822)\end{array}$ & $\begin{array}{l}0.637^{* *} \\
(0.170)\end{array}$ & $\begin{array}{c}0.062 \\
(1.422)\end{array}$ & $\begin{array}{l}-0.092 \\
(-1.428)\end{array}$ \\
\hline Introjected_Motivation & $\begin{array}{l}0.117^{* *} \\
(2.990)\end{array}$ & $\begin{array}{l}-0.102 \\
(0.154)\end{array}$ & $\begin{array}{l}0.098^{*} \\
(2.151)\end{array}$ & $\begin{array}{c}0.113 \\
(1.758)\end{array}$ \\
\hline Identified_Motivation & $\begin{array}{l}0.353^{* *} \\
(7.699)\end{array}$ & $\begin{array}{c}0.274 \\
(0.185)\end{array}$ & $\begin{array}{l}0.328^{* *} \\
(6.479)\end{array}$ & $\begin{array}{c}0.098 \\
(1.171)\end{array}$ \\
\hline Intrinsic_Motivation & $\begin{array}{c}0.018 \\
(0.493)\end{array}$ & $\begin{array}{l}-0.019 \\
(0.144)\end{array}$ & $\begin{array}{c}0.041 \\
(0.983)\end{array}$ & $\begin{array}{c}0.062 \\
(1.039)\end{array}$ \\
\hline Advice_Accountant & $\begin{array}{c}0.315^{* *} \\
(3.120)\end{array}$ & & & $\begin{array}{c}0.114 \\
(0.675)\end{array}$ \\
\hline Quality_Business_Plan & & & & $\begin{array}{l}0.758^{* *} \\
(7.258)\end{array}$ \\
\hline Frequency_Advice & & & $\begin{array}{l}0.011 * \\
(2.252)\end{array}$ & \\
\hline Experience & $\begin{array}{c}0.099 \\
(0.884)\end{array}$ & $\begin{array}{l}1.194 \\
(0.629)\end{array}$ & $\begin{array}{l}0.053 \\
(0.460)\end{array}$ & $\begin{array}{c}0.292 \\
(1.586)\end{array}$ \\
\hline $\begin{array}{l}\text { Business_Management_ } \\
\text { Certificate }\end{array}$ & $\begin{array}{c}0.269^{* *} \\
(3.439)\end{array}$ & $\begin{array}{l}-0.048 \\
(0.309)\end{array}$ & $\begin{array}{c}0.251 * * \\
(2.875)\end{array}$ & $\begin{array}{l}-0.088 \\
(-0.659)\end{array}$ \\
\hline Constant & $\begin{array}{l}1.161^{* * *} \\
(5.765)\end{array}$ & $\begin{array}{l}-1.067 \\
(0.783)\end{array}$ & $\begin{array}{l}1.423^{* *} \\
(6.257)\end{array}$ & $\begin{array}{l}-0.233 \\
(-0.658)\end{array}$ \\
\hline $\begin{array}{l}\text { Observations } \\
\text { Nagelkerke R-squared }\end{array}$ & 254 & $\begin{array}{c}283 \\
0.132\end{array}$ & 202 & 235 \\
\hline Adjusted R-squared & 0.388 & & 0.352 & 0.382 \\
\hline F-statistic & 23.960 ** & & $16.582 * *$ & $19.062 * *$ \\
\hline
\end{tabular}

(a) Linear regression: Non-standard coefficients are displayed, $t$-statistics in parentheses: ${ }^{* *} p<0.01,{ }^{*} p<0.05 .{ }^{\text {(b) }}$ Binary logistic regression: B-coefficients are displayed, standard error statistics in parentheses: ${ }^{* *} p<0.01{ }^{*} p<0.05$.

Furthermore, model 1 showed a significant and positive relationship between the possession of a business management certificate and the quality of a business plan $(p=0.001)$. This finding suggests that entrepreneurs who obtained a business management certificate developed a higher-quality business plan before launching their business than starters who did not obtain the certificate. Consequently, business management training (still) seems to encourage entrepreneurs to reflect thoroughly on the diverse topics of their business plan before launching their business.

Model 2 of the regression analyses showed a significant and positive relationship between external motivation and searching for advice from an external accountant, which 
confirmed Hypothesis 2a $(p<0.001)$. This finding thus indicates that externally motivated entrepreneurs mainly tend to take the advice of an external accountant when developing a business plan. When entrepreneurs are (legally) obliged to develop a business plan, they need to comply with several specific expectations. For example, in Belgium, entrepreneurs who are legally required to develop a business plan need to incorporate (e.g., a projected balance sheet and profit or loss account, the expected income and expenses, and the applied assumptions to achieve their proposed turnover and profitability). These aspects require quite specific knowledge and skills. In order to meet these legally required expectations, entrepreneurs tend to rely on external accountants who are able to advise and help them in the development of their business/financial plan. The data offer no support for Hypotheses $2 b-d$.

Furthermore, the results also show that the advice of an external accountant is positively and significantly related to the quality of the business plan, which confirms Hypothesis 3 (see model $1, p=0.002$ ). This finding suggests that the role of the accountant transcends the mere development of a business plan as such.

In addition, model 3 supported Hypothesis 4, as the regression analysis showed a significant and positive relationship between the frequency of the advice provided by an external accountant and the quality of the business plan $(p=0.025)$. This result indicates that entrepreneurs who frequently consult their external accountant for the development of their business plan create a high-quality business plan.

Finally, the regression analysis in model 4 confirmed Hypothesis 5, as the quality of the business plan was positively and significantly linked to effectiveness $(p<0.001)$. This finding suggests that a high-quality business plan enables entrepreneurs to use their business plan as an effective management instrument. In other words, a thorough reflection on the diverse subjects of a business plan seems to help entrepreneurs to monitor the evolution of the company effectively. In addition, we performed a robustness test using a path analysis in IBM SPSS Amos 22. In [108], the authors stated that "a good fit is reached when the chi-square is insignificant, the CMIN/DF is less than 3, the CFI is on or above 0.95 and when the RMSEA is less than 0.08" (p. 330). The model fit indices showed good values; the chi-square value was insignificant (35.486, $p=0.080$ with 25 degrees of freedom). Furthermore, the CMIN/DF was 1.419, the CFI was 0.977, and the RMSEA was 0.039 . Introjected and identified motivation were significantly and positively related to the quality of the business plan ( $p=0.001$ and $p<0.001$, respectively). This result confirms the finding that entrepreneurs with a high introjected or high identified motivation tend to develop a high-quality business plan. The possession of a business management certificate was also positively and significantly related to the quality of a business plan $(p<0.001)$. Furthermore, externally motivated entrepreneurs tend to rely more on the advice of an external accountant $(p<0.001)$ as external motivation and the advice of an external accountant were positively and significantly related. In addition, the results affirm the positive relationship between the advice of an external accountant and the quality of the business plan $(p<0.001)$. Moreover, the positive relationship between the frequency of advice provided by an external accountant and the quality of the business plan was also confirmed $(p=0.023)$. Finally, the path analysis confirmed the significant and positive relationship between the quality of the business plan and effectiveness $(p<0.001)$.

Figure 2 presents an overview of the results. 


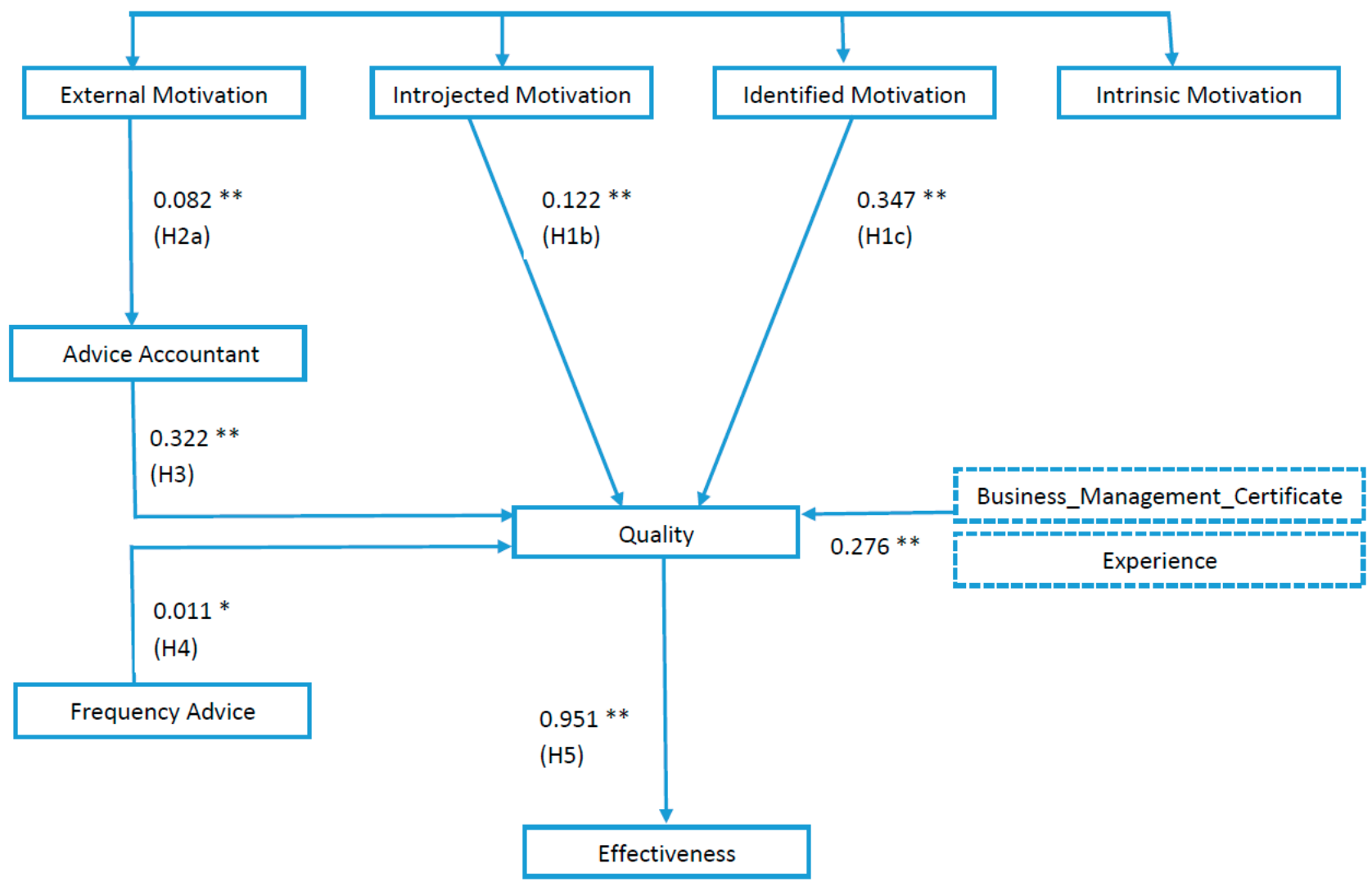

Figure 2. Robustness test (Amos). Correlation is significant: ${ }^{* *} p<0.1 ;{ }^{*} p<0.05$.

\section{Discussion and Conclusions}

This study contributes to the lively debate on the (un)importance of business planning for starters [109-112]. Developing a business plan should support entrepreneurs in making informed decisions, launching their business successfully, and monitoring the overall viability efficiently [7-14,16-20,113]. However, Gonzalez [5] notes that "there is a growing and evolving body of work advising that traditional startup planning has become obsolete and unnecessary" (p. 193). For example, Ries [114] claimed that no money nor time should be wasted on developing traditional formal business plans. Furthermore, several studies found no evidence concerning the value of business planning in terms of survival and/or financial success $[7,29,32,109,110]$. This paper adds insights to the existing literature as it analyzes the quality of a business plan in relation to its effectiveness (i.e., the extent to which a business plan enables entrepreneurs to monitor their business effectively).

Therefore, the first objective of this study was to analyze whether a high-quality business plan actually enables entrepreneurs to monitor their business effectively during the first year after the founding of their business. The results of this study showed that entrepreneurs who reflect thoroughly on diverse aspects of the business plan are more capable of monitoring key indicators (i.e., monitoring financial needs, monitoring the manager's income from the company, and monitoring sales figures as well as preventing liquidity shortages and making decisions to ensure the viability of the company). In this regard, developing a business plan does not seem to be a waste of time for entrepreneurs. These findings are in line with previous research $[7,14,16-20]$ as they suggest that developing a high-quality business plan supports entrepreneurs in managing their business effectively. The development of a business plan should be considered as a learning process, enabling entrepreneurs to make informed decisions [32,115]. Understanding the dynamics of a business is therefore extremely important to anticipate "the unexpected" and to ensure the viability of the company in the short- and long-term $[5,106]$. The true value of a business plan seems to be hidden in the planning process [116], which enables entrepreneurs to 
structure their ideas, to learn, and ultimately to monitor their business effectively. In this sense, the business plan is a manifestation of the underlying learning process (i.e., reflecting on diverse items contained in a business plan) that might cover the true value of business planning. The second objective was to study if the advice of the external accountant supported entrepreneurs in developing a high-quality business plan. We found evidence that the advice of external accountants regarding the business plan was positively related to the quality of said business plan. The results thus confirmed that the advice of an accountant truly supports entrepreneurs to carefully consider and analyze the diverse subjects of the business plan. This finding is in line with previous research that stresses the increasingly important advisory and educational role of the accountant $[79,97,117]$. In order to benefit from the information captured in a business plan, entrepreneurs need to thoroughly understand its dynamics [23,27]. In this regard, external accountants are important advisers as they educate their clients, explain the accounting information in an accessible manner, and enable them to use this information in their decision making process $[39,42,67,70,75]$. This study adds insights to the existing literature as the results indicate that the accountant supports entrepreneurs in developing a high quality business plan. Furthermore, frequent meetings with an external accountant improve the quality of the business plan. This means that an intense cooperation empowers entrepreneurs, which might enable them to internalize specialist knowledge [70,75]. In order to reveal the full potential value of a business plan as an effective management instrument, entrepreneurs should be involved in the process and should understand the content of their business plan. This conclusion is consistent with previous research [5,32,82], and highlights the added value an accountant is able to offer during the business planning stage.

Third, the link between the type of motivation to develop a business plan and the quality of said business plan was analyzed. Based on SDT, four motivational profiles were distinguished: External, introjected, identified, and intrinsic motivation. Externally motivated entrepreneurs develop a business plan because they are legally obliged to do so and/or because they need to convince an investor. The second profile is called introjected motivation; these entrepreneurs develop a business plan because they want to avoid feelings of guilt/shame, or would like to obtain approval. The third profile consists of entrepreneurs with an identified motivation; they develop a business plan because, for example, they want to learn new things and gain insights into the feasibility of their business project. Fourth, intrinsically motivated entrepreneurs develop a business plan because they experience it as exciting and fun. The results showed that entrepreneurs with high introjected or high identified motivation developed a high-quality business plan. This means that they reflected very thoroughly on the diverse topics of the business plan, which in turn enabled them to monitor their business more effectively.

The existing literature points out that a formal business plan is often prepared to comply with (legal) requirements, and/or to obtain external financing $[14,56,57]$. This study showed that these mainly externally motivated entrepreneurs seem to reflect less thoroughly on the diverse topics of the business plan, which prevents them from further increasing their effectiveness. However, they are more likely to rely on the advice of an external accountant to develop their business plan. These entrepreneurs focus on complying with (legal) obligations, which requires specific knowledge and skills that they often do not possess themselves. In Belgium, for example, entrepreneurs who are legally obliged to develop a business plan need to incorporate, for example, a projected balance sheet and profit or loss account, the expected income and expenses, and the applied assumptions to achieve their proposed turnover and profitability. Fulfilling these requirements often implies recourse to an external accountant who is able to offer support. However, imposing external regulations in order to force a desired outcome is not always the most effective approach $[48,53]$. Therefore, the government might also need to communicate the importance of these legal requirements. At the moment, not every entrepreneur seems to be aware and/or convinced of the value of business planning. However, in order to be effective, the legislation needs to be fully implemented. In this regard, a powerful 
communication strategy might be necessary. When externally motivated entrepreneurs truly understand the rationale of this legal requirement, their engagement in business planning and subsequent effectiveness might increase significantly.

These findings revealed several challenges and opportunities for the accounting practice. During the business planning stage, accountants transcend their traditional role, in which they offer support to comply with legal requirements. However, in line with previous research focusing on the role of external accountants as business advisers [97,117], it seems that their service provision during the planning stage is not exploited to its full extent. External accountants guide their client entrepreneurs during the development of a business plan and the actual launch of a business. They function as coaches who are able to challenge the business plan and to fill potential knowledge gaps [54,70,71]. Furthermore, they offer support to process information, to ensure that a business plan is complete [70], and to evaluate if the proposed business project is viable $[19,35]$. Accountants act as a sounding board or sparring partner who pursue the same goal [97], but is capable of providing a critical and objective second opinion [19,35]. Professional accounting bodies as well as the accounting practice in general might need to (further) invest in increasing the awareness of entrepreneurs.

Previous research has identified different entrepreneurial learning styles, leading to differences in reliance on sources of social networks [115]. This study also found that the underlying motivation of entrepreneurs to develop a business plan is an important determinant in their decision to rely on an external accountant. Therefore, accountants could further optimize their guidance depending on the motivational profile of their client entrepreneur. It seems that entrepreneurs still mainly rely on their external accountant to meet (legal) requirements and/or the expectations of third parties. These rather externally motivated entrepreneurs might need an extra tailor-made explanation to engage in the business planning process. Recognizing the value of the start-up advice provided by their accountant could encourage them to internalize their initial external motivation. Consultations that originate from an external motivation thus offer an opportunity for external accountants to demonstrate the potential value of their service provision. The authors in [49] pointed out that supporting factors for the integration of external pressure showed noteworthy similarities with the aspects of communication, empathy, and involvement. Listening to their client entrepreneur and understanding their vision is essential to enhancing cooperation [70,79,97].

Therefore, developing a high-quality business plan requires a tailor-made approach. In this respect, the business plan becomes a management instrument that supports the entrepreneur and the external accountant in understanding one another and acting as peers who pursue the same goal. The true value of business planning might be hidden in the process of developing a business plan, rather than in achieving a perfect business plan as a product. A valuable business plan functions as an instrument that enables entrepreneurs to understand and monitor the dynamics of their business, instead of being a mere static document. A business plan is never finished, rather, it is a never-ending learning process in which all relevant aspects should be considered in order to improve entrepreneurial effectiveness.

Notwithstanding the contribution of this study, it suffers some limitations. These limitations open avenues for future research. First, this study was executed in the Belgian context, which is characterized by quite a specific legal framework concerning the development of a financial plan. It would be beneficial to broaden the geographical scope and analyze this topic in other countries as perhaps the underlying motivation of entrepreneurs to develop a business plan is different in other countries. Diverse (entrepreneurial) cultures, norms, and legal environments could influence entrepreneurial motivation to develop a business plan. Therefore, future studies could test the developed measures in other entrepreneurial environments and study the potential differences in more detail. Second, the guidance provided by external accountants during the planning stage and the legal framework might also be different in other countries. Moreover, it would be interesting 
to study the accountant's point of view. In particular, whether they actually experience differences in the motivation of entrepreneurs to develop a business plan and if so, how they can adjust their approach to optimize their service provision. Further research could elaborate on the question of how external advisers could facilitate motivation in order to increase entrepreneurial capabilities. Third, it would be interesting to study the content of services provided by external accountants to starters in more detail. Do entrepreneurs struggle with very specific subjects or themes concerning the development of a business plan? These insights could support accountants in further optimizing their role as a coach. Educational institutions might also benefit from further profound analyses on the substantial difficulties that entrepreneurs face. As the educational role of accountants is increasing in importance, it would be valuable to develop hands-on case studies that prepare students for these challenges. Fourth, the quality of the business plan is operationalized as the perceived quality by the starter. Therefore, it measures how important it is for them, as an entrepreneur, to thoroughly reflect on a specific list of subjects, usually captured in a business plan. The results may suffer from a common method bias as the motivation, perceived quality, and perceived effectiveness were measured by the same online survey. Fifth, we acknowledge the limited sample size and the limited number of control variables included in this study. Finally, it would definitely be interesting to further elaborate on this topic in future longitudinal research, in which the pre- and post-knowledge of entrepreneurs as well as the planning process would be linked to the quality and effectiveness of a business plan.

Author Contributions: Conceptualization, S.D.B. and P.E.; Methodology, S.D.B. and P.E.; Software, S.D.B. and P.E.; Validation, S.D.B. and P.E.; Formal analysis, S.D.B. and P.E.; Investigation, S.D.B. and P.E.; Resources, S.D.B. and P.E.; Data curation, S.D.B.; Writing-original draft preparation, S.D.B. and P.E.; Writing-review and editing, S.D.B. and P.E.; Visualization, S.D.B. and P.E.; Supervision, P.E.; Project administration, S.D.B.; Funding acquisition, S.D.B. and P.E. All authors have read and agreed to the published version of the manuscript.

Funding: This research was funded by the Research Fund of HOGENT University of Applied Sciences and Arts.

Data Availability Statement: The data presented in this study are available on request from the corresponding author. The data are not publicly available due to privacy restrictions.

Acknowledgments: The authors gratefully acknowledge the support of the Research Fund of HOGENT University of Applied Sciences and Arts. Furthermore, they are grateful for all of the feedback provided by Annelies Roggeman, Carine Coppens, and Gerrit Sarens.

Conflicts of Interest: The authors declare no conflict of interest. The funders had no role in the design of the study; in the collection, analyses, or interpretation of data; in the writing of the manuscript, or in the decision to publish the results.

\section{References}

1. European Commission. Entrepreneurship and Small and Medium-Sized Enterprises (SMEs). Available online: https:/ / ec.europa. eu/growth/smes_en (accessed on 1 December 2020).

2. European Commission. Unleashing the Full Potential of EUROPEAN SMEs. Available online: https://ec.europa.eu/commission/ presscorner/detail/en/fs_20_426 (accessed on 1 December 2020).

3. SDG Compass. The Guide for Business Action on the SDGs. Available online: https://sdgcompass.org/ (accessed on 1 December 2020).

4. European Commission. SME Performance Review (Annual Report on European SMEs). Available online: https: / / ec.europa.eu/ growth/smes/business-friendly-environment/performance-review_en\#annual-report (accessed on 20 November 2019).

5. Gonzalez, G. Startup Business Plans: Do Academic Researchers and Expert Practitioners Still Disagree? Muma Bus. Rev. 2017, 1, 189-197. [CrossRef]

6. Gonzalez, G. Risk Analysis for Initial Needs (RAIN): Improving a Time Zero Startup Plan through Resource Based Auditing (RBA) and a Launch Focused Strategy. Muma Bus. Rev. 2017, 1, 37-52. [CrossRef]

7. Fernández-Geurrero, R.; Revuelto-Taboada, L.; Simón-Moya, V. The business plan as a project: An evaluation of its predictive capability for business success. Serv. Ind. J. 2012, 32, 2399-2420. [CrossRef]

8. Dearman, D.T. Factors Influencing Managers' Decisions to Prepare a Business Plan. 2012. Available online: https://ssrn.com/ abstract=2133100 (accessed on 18 August 2016). 
9. Burke, A.; Fraser, S.; Greene, F.J. The Multiple Effects of Business Planning on New Venture Performance. J. Manag. Stud. 2010, 47, 391-415. [CrossRef]

10. Karlsson, T.; Honig, B. Judging a business by its cover: An institutional perspective on new ventures and the business plan. J. Bus. Ventur. 2009, 24, 27-45. [CrossRef]

11. Kirsch, D.; Goldfarb, B.; Gera, A. Form or substance: The role of business plans in venture capital decision making. Strateg. Manag. J. 2009, 30, 487-515. [CrossRef]

12. Scott, J.M.; Irwin, D. Discouraged Advisees? The Influence of Gender, Ethnicity, and Education in the Use of Advice and Finance by UK SMEs. Environ. Plan. C Gov. Policy 2009, 27, 230-245. [CrossRef]

13. Mazzarol, T. Do Formal Business Plans Really Matter? An Exploratory Study of Small Business Owners in Australia. Small Enterp. Res. 2001, 9, 32-45. [CrossRef]

14. Delmar, F.; Shane, S. Does Business Planning Facilitate the Development of New Ventures? Strateg. Manag. J. 2003, 24, 1165-1183. [CrossRef]

15. Botha, M.; Robertson, C.L. Potential entrepreneurs' assessment of opportunities through the rendering of a business plan. S. Afr. J. Econ. Manag. Sci. 2014, 3, 249-265. [CrossRef]

16. Barraket, J.; Furneaux, C.; Barth, S.; Mason, C. Understanding Legitimacy Formation in Multi-Goal Firms: An Examination of Business Planning Practices among Social Enterprises. J. Small Bus. Manag. 2016, 54, 77-89. [CrossRef]

17. Zimmerman, J. Using Business Plans for Teaching Entrepreneurship. Am. J. Bus. Educ. 2012, 5, 727-742. [CrossRef]

18. Mainprize, B.; Hindle, K. The Benefit: A Well-Written Entrepreneurial Business Plan is to an Entrepreneur What a Midwife is to an Expecting Mother. J. Priv. Equity 2007, 11, 40-52. [CrossRef]

19. Hormozi, A.M.; Sutton, G.S.; McMinn, R.D.; Lucio, W. Business Plans for new or small businesses: Paving the path to success. Manag. Decis. 2002, 40, 755-763. [CrossRef]

20. Bianchi, C.; Winch, G.; Grey, C. The business plan as a learning-oriented tool for small/medium enterprises: A business simulation approach. In Proceedings of the 16th International System Dynamics Society Conference, Québec City, QC, Canada, 20-23 July 1998.

21. Karadag, H. Financial Management Challenges in Small and Medium-sized Enterprises: A Strategic Management Approach. Emerg. Mark. J. 2015, 5, 26-40. [CrossRef]

22. Baker, W.H.; Addams, H.L.; Davis, B. Business Planning in Successful Small Firms. Long Range Plan. 1993, 26, 82-88. [CrossRef]

23. Papazov, E.; Mihaylova, L. Linking accounting information with business planning in Bulgarian SMEs. In Proceedings of the 8th International Management Conference, Bucharest, Romania, 6-7 November 2014.

24. Ferreira, J.J.; Azevedo, S.; Cruz, R. SME Growth in the Service Sector: A Taxonomy Combining Life-Cycle and Resource-Based Theories. Serv. Ind. J. 2011, 31, 251-271. [CrossRef]

25. Bagire, V.; Namada, J. Managerial Skills, Financial Capability and Strategic Planning in Organizations. Am. J. Ind. Bus. Manag. 2013, 3, 480-487. [CrossRef]

26. Brinckmann, J.; Salomo, S.; Gemuenden, H.G. Financial Management Competence of Founding Teams and Growth of New Technology-Based Firms. Entrep. Theory Pract. 2011, 217-243. [CrossRef]

27. Halabi, A.K.; Barrett, R.; Dyt, R. Understanding Financial Information Used to Assess Small Firm Performance. An Australian qualitative study. Qual. Res. Account. Manag. 2010, 7, 163-179. [CrossRef]

28. Gruber, M. Uncovering the value of planning in new venture creation: A process and contingency perspective. J. Bus. Ventur. 2007, 22, 782-807. [CrossRef]

29. Honig, B.; Karlsson, A. Institutional forces and the written business plan. J. Manag. 2004, 30, 29-48. [CrossRef]

30. Mason, C.; Stark, M. What do investors look for in a business plan? A comparison of the investment criteria of bankers, venture capitalists and business angels. Int. Small Bus. J. 2004, 22, 227-248. [CrossRef]

31. Gorton, M. Use of Financial Management Techniques in the U.K.-Based Small and Medium-Sized Enterprises: Emperical Research Findings. J. Financ. Manag. Anal. 1999, 12, 56-64.

32. Zinger, T.J.; LeBrasseur, R. The Benefits of Business Planning in Early Stage Small Enterprises. J. Small Bus. Entrep. 2003, 17, 1-15. [CrossRef]

33. Ciemleja, G.; Lace, N. The Model of Sustainable Performing of SMEs in Context of Company's Life Cycle. In Proceedings of the 15th World Multi-Conference on Systemics, Cybernetics and Informatics, Orlando, FL, USA, 19-22 July 2011.

34. Hanlon, D.; Saunders, C. Marshaling Resources to Form Small New Ventures: Toward a More Holistic Understanding of Entrepreneurial Support. Entrep. Theory Pract. 2007, 31, 619-641. [CrossRef]

35. Deakins, D.; Logan, D.; Steele, L. The Financial Management of the Small Enterprise; ACCA: London, UK, 2001.

36. Vera-Colina, M.A.; Rodríguez-Medina, G.; Melgarejo-Molina, Z. Financial planning and access to financing in small and medium-sized companies in the Venezuelan manufacturing sector. Innovar 2011, 21, 99-112.

37. Smeltzer, L.R.; Van Hook, B.L.; Hutt, R.W. Analysis of the Use of Advisers as Information Sources in Venture Startups. J. Small Bus. Manag. 1991, 29, 10-20.

38. Blackburn, R.; Jarvis, R. The Role of Small and Medium Practices in Providing Business Support. to Small-and Medium-Sized Enterprises; Information Paper; International Federation of Accountants: Geneva, Switzerland, 2010.

39. Oosthuizen, A.; van Vuuren, J.; Botha, M. Compliance or management: The benefits that small business owners gain from frequently sourcing accounting services. S. Afr. J. Entrep. Small Bus. Manag. 2020, 12, 2071-3185. [CrossRef] 
40. Carey, P.; Tanewski, G. The Provision of Business Advice to SMEs by External Accountants. Manag. Audit. J. 2016, 31, 290-313. [CrossRef]

41. Lybaert, N.; Zeelmaekers, N. De rol van de externe accountant binnen de Vlaamse micro-onderneming. Account. Bedrijfskd. 2016, $15,38-54$.

42. Catto, C. Role of Strategic Planning, Accounting Information and Advisors in the Growth of Small to Medium Enterprises. Asia-Pac. Manag. Account. J. 2016, 11, 59-78.

43. Barbera, F.; Hasso, T. Do We Need to Use an Accountant? The Sales Growth and Survival Benefits to Family SMEs. Fam. Bus. Rev. 2013, 26, 271-292. [CrossRef]

44. Carey, P.J. External accountants' business advice and SME performance. Pac. Account. Rev. 2015, 27, 166-188. [CrossRef]

45. Berry, A.J.; Sweeting, R.; Goto, J. The effect of business advisers on the performance of SMEs. J. Small Bus. Enterp. Dev. 2006, 13, 33-47. [CrossRef]

46. Accounting Standards Commission-Commissie Voor Boekhoudkundige Normen. Financieel Plan Voor Besloten Vennootschappen, Coöperatieve Vennootschappen en Naamloze Vennootschappen, Technische Nota van 4 maart 2020 (TN 2020/04). Available online: https:/ / www.cbn-cnc.be/nl/adviezen/technische-nota-financieel-plan-voor-besloten-vennootschappen-cooperatievevennootschappen (accessed on 12 April 2020).

47. Ooghe, H.; Vander Bauwhede, H.; Van Wymeersch, C. Financiële Analyse van de Onderneming—Deel 1, 5th ed.; Intersentia: Antwerp, Belgium, 2017; pp. 1-630.

48. Ryan, R.M.; Deci, E.L. A self-determination theory approach to psychotherapy: The motivational basis for effective change. Can. Psychol. Psychol. Can. 2008, 49, 186-193. [CrossRef]

49. Gagné, M.; Deci, E.L. Self-Determination Theory and Work Motivation. J. Organ. Behav. 2005, 26, 331-362. [CrossRef]

50. Ryan, R.M.; Deci, E.L. Intrinsic and Extrinsic Motivations: Classic Definitions and New Directions. Contemp. Educ. Psychol. 2000, 25, 54-67. [CrossRef]

51. Ryan, R.M.; Deci, E.L. Self-Determination Theory and the Facilitation of Intrinsic Motivation, Social Development and Well-Being. Am. Psychol. 2000, 55, 68-78. [CrossRef]

52. Deci, E.L.; Ryan, R.M. The general causality orientations scale: Self-determination in personality. J. Res. Personal. 1985, 19, 109-134. [CrossRef]

53. Vansteenkiste, M.; Sierens, E.; Soenens, B.; Luyckx, K.; Lens, W. Motivational Profiles from a Self-Determination Perspective: The Quality of Motivation Matters. J. Educ. Psychol. 2009, 101, 671-688. [CrossRef]

54. Delanoë, S. From intention to start-up: The effect of professional support. J. Small Bus. Enterp. Dev. 2013, 20, 383-398. [CrossRef]

55. Hagger, M.S.; Chatzisarantis, N.L.; Biddle, S.J. The influence of autonomous and controlling motives on physical activity intentions within the Theory of Planned Behaviour. Br. J. Health Psychol. 2002, 7, 283-297. [CrossRef]

56. Dearman, D.T.; Bell, J.R. Context and Person Characteristics Associated with the Decision to Prepare a Business Plan. Small Bus. Inst. J. 2012, 8, 1-15.

57. Karlsson, T.; Honig, B. Norms surrounding business plans and their effect on entrepreneurial behavior. Front. Entrep. Res. 2007, $27,1-11$.

58. Ryan, R.M.; Connell, J.P. Perceived Locus of Causality and Internalization: Examining Reasons for Acting in Two Domains. J. Personal. Soc. Psychol. 1989, 57, 749-761. [CrossRef]

59. Vansteenkiste, M.; Sheldon, K.M. There's nothing more practical than a good theory: Integrating motivational interviewing and self-determination theory. Br. J. Clin. Psychol. 2006, 45, 63-82. [CrossRef]

60. Vansteenkiste, M.; Lens, W.; De Witte, H.; Feather, N.T. Understanding unemployed people's job search behavior, unemployment experience and well-being: A comparison of expectancy-value theory and self-determination theory. Br. J. Soc. Psychol. 2005, 44, 269-287. [CrossRef] [PubMed]

61. Al-Jubari, I.; Hassan, A.; Liñán, F. Entrepreneurial intention among University students in Malaysia: Integrating self-determination theory and the theory of planned behavior. Int. Entrep. Manag. J. 2018, 15, 1323-1342. [CrossRef]

62. Hardre, P.L.; Reeve, J. A motivational modal of rural students' intentions to persist in, versus drop out of, high school. J. Educ. Psychol. 2003, 95, 347-356. [CrossRef]

63. Pelletier, L.G.; Fortier, M.S.; Vallerand, R.J.; Brière, N.M. Associations among perceived autonomy support, forms of self-regulation, and persistence: A prospective study. Motiv. Emot. 2001, 25, 279-306. [CrossRef]

64. Yusoff, N.M.H. Supporting the Development of SMEs: Bridging the Services Gap. Account. Today 2006, 19, 12-14.

65. Chrisman, J.J. The Influence of Outsider-Generated Knowledge Resources on Venture Creation. J. Small Bus. Manag. 1999, $37,42-58$.

66. Dyer, L.M.; Ross, C.A. Seeking Advice in a Dynamic and Complex Business Environment: Impact on the Success of Small Firms. J. Dev. Entrep. 2008, 13, 133-149. [CrossRef]

67. Sian, S.; Roberts, C. UK small owner-managed businesses: Accounting and financial reporting needs. J. Small Bus. Enterp. Dev. 2009, 16, 289-305. [CrossRef]

68. Blackburn, R.; Carey, P.; Tanewski, G.A. Business Advice to SMEs: Professional Competence, Trust and Ethics; ACCA: London, UK, 2010.

69. Everaert, P.; Sarens, G.; Rommel, J. Using Transaction Cost Economics to Explain Outsourcing of Accounting. Small Bus. Econ. 2010, 35, 93-112. [CrossRef] 
70. Chrisman, J.J.; McMullan, E.; Hall, J. The influence of guided preparation on the long-term performance of new ventures. J. Bus. Ventur. 2005, 20, 769-791. [CrossRef]

71. Bennett, R.J.; Robson, P.J.A. The Advisor-SME Client Relationship: Impact, Satisfaction and Commitment. Small Bus. Econ. 2005, 25, 255-271. [CrossRef]

72. Mole, K. (Seeking, Acting on and Appreciating) the Value of Business Advice; ERC Research Paper No.44; Enterprise Research Center: Birmingham, UK, 2016.

73. Mole, K.; North, D.; Baldock, R. Which SMEs Seek External Support? Business characteristics, Management Behaviour and External Influences in a Contingency Approach. Environ. Plan. C Gov. Policy 2016, 35, 1-48. [CrossRef]

74. Cassar, G.; Ittner, C.D. Initial Retention of External Accountants in Startup Ventures. Eur. Account. Rev. 2009, 18, 313-340. [CrossRef]

75. Chrisman, J.J.; McMullan, W.E. Outsider Assistance as a Knowledge Resource for New Venture Survival. J. Small Bus. Manag. 2004, 42, 229-244. [CrossRef]

76. Vansteenkiste, M.; Lens, W.; Deci, E.L. Intrinsic versus extrinsic goal-contents in self-determination theory: Another look at the quality of academic motivation. Educ. Psychol. 2006, 41, 19-31. [CrossRef]

77. Mole, K.; Hart, M.; Roper, S.; Saal, D. Assessing the effectiveness of business support services in England: Evidence from a theory based evaluation. Int. Small Bus. J. Res. Enterp. 2009, 27, 557-582. [CrossRef]

78. Veskaisri, K.; Chan, P.; Pollard, D. Relationship between Strategic Planning and SME Success: Empirical Evidence from Thailand. In Proceedings of the 12th Annual Conference Joined with the 9th International DSI Conference, Bangkok, Thailand, 11-15 July 2007.

79. Blackburn, R.; Carey, P.; Tanewski, G. Business Advice by Accountants to SMEs: Relationships and Trust. Qual. Res. Account. Manag. 2018, 15, 1-42. [CrossRef]

80. Brinckmann, J.; Dew, N.; Read, S.; Mayer-Haug, K.; Grichnik, D. Of those who plan: A meta-analysis of the relationship between human capital and business planning. Long Range Plan. 2019, 52, 173-188. [CrossRef]

81. Pansiri, J.; Temtime, Z.T. Linking Firm and Managers' Characteristics to perceived critical success factors for innovative entrepreneurial support. J. Small Bus. Enterp. Dev. 2010, 17, 45-59. [CrossRef]

82. Cook, R.G.; Belliveau, P.; Sandberg, M.E. Training and learning as drivers of US microenterprise business plan quality. Educ. Train. 2004, 46, 398-405. [CrossRef]

83. Chwolka, A.; Raith, M.G. The value of business planning before start-up-A decision-theoretical perspective. J. Bus. Ventur. 2012, 27, 385-399. [CrossRef]

84. Brews, P.J.; Hunt, M.R. Learning to Plan and Planning to Learn: Resolving the Planning School/Learning School Debate. Strateg. Manag. J. 1999, 20, 889-913. [CrossRef]

85. Hannon, P.D.; Atherton, A. Small firm success and the art of orienteering: The value of plans, planning, and strategic awareness in the competitive small firm. J. Small Bus. Enterp. Dev. 1998, 5, 102-119. [CrossRef]

86. Haag, A.B. Writing a successful Business Plan: An Overview. Workplace Health Saf. 2013, 61, 19-29. [CrossRef]

87. Drucker, P.F. The Age of Discontinuity: Guidelines to Our Changing Society, 2nd ed.; Routledge: New York, NY, USA, 1992; pp. 1-420.

88. Salazar, A.L.; Soto, R.C.; Mosqueda, R.E. The impact of financial decisions and strategy on small business competitiveness. Glob. J. Bus. Res. 2012, 6, 93-103.

89. Jasra, J.; Hunjra, A.I.; Rehman, A.U.; Azam, R.I.; Khan, M.A. Determinants of Business Success of Small and Medium Enterprises. Int. J. Bus. Soc. Sci. 2011, 2, 274-280.

90. Masurel, E.; Van Montfort, K. Life Cycle Characteristics of Small Professional Service Firms. J. Small Bus. Manag. 2006, 44, 461-473. [CrossRef]

91. Picken, J.C. From startup to scalable enterprise: Laying the foundation. Bus. Horiz. 2017, 60, 587-595. [CrossRef]

92. Teddlie, C.; Yu, F. Mixed Methods Sampling. A Typology with Examples. J. Mix. Methods Res. 2007, 1, 77-100. [CrossRef]

93. Neckebroeck, C.; Vanderstraeten, I.; Verhaeghe, M. Onderzoeksvaardigheden. Voor Onderwijs, Zorg en Welzijn, 2nd ed.; Uitgeverij VAN IN: Wommelgem, Belgium, 2018.

94. Baltar, F.; Brunet, I. Social research 2.0: Virtual snowball sampling method using Facebook. Internet Res. 2012, 22, 57-74. [CrossRef]

95. Alberti, F.G.; Pizzurno, E. Oops, I did it again! Knowledge leaks in open innovation networks with start-ups. Eur. J. Innov. Manag. 2017, 20, 50-79. [CrossRef]

96. Ghee, W.Y.; Ibrahim, M.D.; Abdul-Halim, H. Family Business Succession Planning: Unleashing the Key Factors of Business Performance. Asian Acad. Manag. J. 2015, 20, 103-126.

97. De Bruyckere, S.; Verplancke, F.; Everaert, P.; Sarens, G.; Coppens, C. The Importance of Mutual Understanding Between External Accountants and Owner-Managers of SMEs. Aust. Account. Rev. 2020, 30, 4-21. [CrossRef]

98. Deci, E.L.; Ryan, R.M. Facilitating Optimal Motivation and Psychological Well-Being Across Life's Domains. Can. Psychol. 2008, 49, 14-23. [CrossRef]

99. Quinn, R.E.; Cameron, K. Organizational Life Cycles and Shifting Criteria of Effectiveness: Some Preliminary Evidence. Manag. Sci. 1983, 29, 33-51. [CrossRef]

100. Zammuto, R.F. A Comparison of Multiple Constituency Models of Organizational Effectiveness. Acad. Manag. Rev. 1984, 9 , 606-616. [CrossRef] 
101. Ramanujam, V.; Venkatraman, N. Planning System Characteristics and Planning Effectiveness. Strateg. Manag. J. 1987, 8 , 453-468. [CrossRef]

102. Churchill, N.; Lewis, V. The Five Stages of Small Business Growth. Harv. Bus. Rev. 1983, 61, 30-50.

103. Frková, J.; Kaderábková, B. SME life cycle model under globalization. In Proceedings of the 9th International Days of Statistics and Economics, Prague, Czech Republic, 10-12 September 2015.

104. Illés, C.B.; Hurta, H.; Dunay, A. Efficiency and profitability along the lifecycle stages of small enterprises. Int. J. Manag. Enterp. Dev. 2015, 14, 56-69. [CrossRef]

105. Zinger, T.J.; Lebrasseur, R.; Zanibbi, L.R. Factors Influencing Early Stage Performance in Canadian Microenterprises. J. Dev. Entrep. 2001, 6, 129-150.

106. Gonzalez, G. What factors are causal to survival of a start-up? Muma Bus. Rev. 2017, 1, 97-114. [CrossRef]

107. Albuquerque, A.F.; Filho, E.E.; Nagano, M.S.; Philippsen, L.A. A change in the importance of mortality factors throughout the life cycle stages of small businesses. J. Glob. Entrep. Res. 2016, 6, 1-18. [CrossRef]

108. Schreiber, J.B.; Nora, A.; Stage, F.K.; Barlow, E.A.; King, J. Reporting Structural Equation Modeling and Confirmatory Factor Analysis Results: A Review. J. Educ. Res. 2006, 99, 323-337. [CrossRef]

109. Honig, B.; Samuelsson, M. Business planning by intrapreneurs and entrepreneurs under environmental uncertainty and institutional pressure. Technovation 2021, 99, 1-12. [CrossRef]

110. Honig, B.; Samuelsson, M. Planning and the entrepreneur: A longitudinal examination of nascent entrepreneurs in Sweden. J. Small Bus. Manag. 2012, 50, 365-388. [CrossRef]

111. Mansoori, Y.; Lackéus, M. Comparing effectuation to discovery-driven planning, prescriptive entrepreneurship, business planning, lean start-up and design thinking. Small Bus. Econ. 2020, 54, 791-818. [CrossRef]

112. Blank, S. Why the Lean Start-Up Changes Everything. Harv. Bus. Rev. 2013, 91, 63-72.

113. Hopp, C.; Greene, F.J. In pursuit of time: Business plan sequencing, duration and intraentrainment effects on new venture viability. J. Manag. Stud. 2018, 55, 320-351. [CrossRef]

114. Ries, E. The Lean Startup: How Today's Entrepreneurs Use Continuous Innovation to Create Radically Successful Businesses, 1st ed.; Crown Business: New York, NY, USA, 2011.

115. Honig, B.; Hopp, C. Learning orientations and learning dynamics: Understanding heterogeneous approaches and comparative success in nascent entrepreneurship. J. Bus. Res. 2019, 94, 28-41. [CrossRef]

116. Mazzarol, T.; Reboud, S. Entrepreneurship and Innovation. Theory, Practice and Context, Springer Texts in Business and Economics, 4th ed.; Singapore Pte Ltd.: Singapore, Singapore, 2020; pp. 191-225.

117. De Bruyckere, S.; Verplancke, F.; Everaert, P.; Sarens, G.; Coppens, C. The Role of External Accountants as Service Providers for SMEs: A Literature Review. Account. Bedrijfskd. 2017, 4, 49-62. 